\title{
ІНФОРМАЦІЙНЕ ПОВІДОМЛЕННЯ
}

\section{IX Міжнародний симпозіум «Актуальні проблеми біофізичної медицини»}

312 по 15 травня 2016 р. Міжнародна академія проблем гіпоксії та Національна академія наук України спільно з Науково-дослідним медико-інженерним центром «НОРТ» та Інститутом фізіології ім. О.О.Богомольця у м. Києві провели IX Міжнародний симпозіум «Актуальні проблеми біофізичної медицини». На 5 засіданнях, що відбулися за ці дні, було заслухано та обговорено 33 доповіді. Більшість 3 них стосувалася принципів немедикаментозного лікування природними чинниками та інноваційними технологіями, апаратури інструментальних впливів на стан здоров'я людини. У перервах між засіданнями кияни і гості столиці мали можливість ознайомитись 3 матеріалами стендів (28), автори яких знаходилися поруч, давали пояснення та відповідали на запитання. У збірці тез, що видана трьома мовами за кілька днів до початку симпозіуму, опубліковано 72 праці від авторів з 11 країн.

Перше засідання відкрив академік НАН України, директор Інституту фізіології О.Кришталь. Після нього академік НАН України І.Магура, присвятив свій виступ біофізичним властивостям іонних каналів та індивідуальних нейронів. Доповідь супроводжувалась яскравою демонстрацією та детальним обговоренням проблеми сигнальної активності нейронів за різних умов існування. Наступна доповідь від Харківського Національного університету ім. В.Каразіна стосувалася впливу варіації атмосферної, космічної погоди і геофізичних полів на стан здоров'я людини. Професор Л.Черногор переконливо підтвердив істотність змін фізіологічних реакцій населення за різних погодних умов. 3 великим інтересом прослухали виступ академіка О.Чалого (від Національного медичного університету ім.О.О.Богомольця) 3 інтригуючою назвою «Нові загадкові та унікальні властивості води». Виявилося, що наші знання про цей найбільш вагомий компонент організму тварин та людини вивчений недостатньо і потребує пильної уваги майбутніх дослідників. Присутні мали можливість не тільки задати питання та вислухати відповіді, але й висловити власну думку 3 піднятих проблем.

Вечірнє засідання 12.05 .2016 р. відкрилося доповіддю професора В.Березовського «Парадигма здоров'я людства - інтегральна медицина». Автор проаналізував ступінь забруднення території України та Росії, показав пов'язані з цим захворювання та перспективність використання для їх лікування не тільки лікарських засобів, але й інноваційних біофізичних методів поліпшення стану здоров'я населення. Другою виступила Голова Державного експертного центру МОЗ України О.Матвєєва. Вона розповіла про побічну дію лікарських засобів і пов'язані з цим міфи та реалії. Наведено приклади негативного впливу недостатньо вивчених препаратів та засобів посилення контролю за можливими ускладненнями фармакотерапії. Наступну доповідь англійською мовою зробив наш гість 3 Варшави професор М.Покорський. Вона була присвячена оцінці гіпоксичного впливу на регуляцію зовнішнього дихання. На переконливих прикладах він показав як індивідуальні відмінності чутливості рецепторів на вміст кисню в середовищі, так і можливість істотного функціонального переходу чутливості цих рецепторів на новий рівень. Особливо яскраво ці відмінності виявлено під час тривалого впливу газових сумішей 3 низьким вмістом кисню порівняно $з$ пере- 
ривчастою дією нормобаричної гіпоксії. 3 великим інтересом було заслухано доповідь професора Х.Мурадяна від Інституту геронтології НАМН України, який поставив перед собою і перед аудиторією питання, чи може штучно керована атмосфера бути фактором прекондиціювання і перепрограмовувати плюрипотентні стовбурові клітини? Проведені ним і колективом його лабораторії експерименти дають підстави стверджувати, що штучні газові суміші зі зниженим вмістом кисню і підвищеним вмістом вуглекислого газу можуть бути дієвим інструментом для перепрограмування стовбурових клітин та усунення помилок в їх генетичних програмах. Доповідь та обговорення проведено англійською мовою.

Ще більше цікавості в аудиторії викликав виступ представника Алтайського державного медичного університету (Барнаул) професора В.Кулікова - «Гиперкапническая гипоксия - эффективное средство цитопротекции, профилактики и лечения заболеваний». Понад 20 років тому ним була сформульована гіпотеза, що гіперкапнія потенціює цитопротекторні впливи гіпоксії, а сполучення цих двох факторів - ефективний засіб попередження та лікування хвороб. На щурах комбінований вплив подовжує наявність біоелектричних проявів діяльності мозку до 270 \%. Заключна доповідь другого засідання була присвячена антигіпоксантним ефектам мелатоніну та можливості їх посилення за допомогою дипіридамолу. Роботу виконано у Буковинському державному медичному університеті (Чернівці) професором І.Заморським. В експериментах на щурах показано, що попереднє введення мелатоніну здійснює значний нейропротекторний ефект до дії гострої гіпоксії. Водночас застосування дипіридамолу істотно не впливає на утворення продуктів ліпідної і білкової пероксидації та на активність внутрішньоклітинних $\mathrm{Na}^{+}, \mathrm{K}^{+}$АТФаз.

Виступом професора О.Яковлевої «Негативна динаміка функціональних тестів погір- шує прогноз ХОЗЛ (хронічної обсруктивної хвороби легенів) при кардіальній коморбідності» (Вінницький НМУ ім. М.Пирогова) відкрилося третє засідання симпозіуму 13.05.2016 р. Другим доповідачем цього засідання став професор В.Валензі (Італія-Швейцарія). Він навів приклади зовнішнього впливу таблетованих лікарських засобів через рецепторні утворення шкіри, без перорального використання. Автор пояснює таку дію квантовими механізмами. Переконливі докази позитивного впливу стимуляційної терапії та гірського клімату на різні варіанти деменції навів професор Дж.Доре (Італія). Особливості реакції центральної гемодинаміки на дію дротаверину в умовах середньогір'я були наведені професором А.Бакуновського (Київ). Дослідженням на культурі мезенхімальних стовбурових клітин людини було присвячено матеріали Л.Плотнікової (Київ), яка виявила можливість прискорювати проліферацію цих клітин за допомогою дозованого зниження парціального тиску кисню.

Вечірнє засідання 13.05.2016 р. відкрив професор Є. Чумаченко (Париж). Його робота була присвячена розробці критерію об'єктивної оцінки ноцицепції та оптимізації знеболювання при травматичних пошкодженнях. Наступним виступив професор А.Гоженко (Одеса). Він висвітлив сучасні уявлення про механізми регуляції водно-сольового гомеостазису, порушення якого бувають причиною різноманітних форм клінічної патології. Анальгетичним ефектом поляризованого світла було присвячено матеріали професора С.Гуляра та 3.Тамарової (Київ). Інноваційний матеріал про новий біофізичний метод ранньої діагностики стану печінки (У3-стеатометрії) було надано у доповіді О.Динника (Київ-Харків). Не менш цікавий матеріал представили учасники симпозіуму К.Апихтін, В.Петрухін, Ю.Горго (Київ-Москва). Вони показали широкі можливості нового варіанту аналізу варіабельності ритму серця та поліпшення функціонального стану міокарда за допомогою сеансів 
інструментальної оротерапії. Синергічному впливу високочастотного електрозварювання на структурну впорядкованість тканин було присвячено доповідь професора А.Вазиної (Москва-Київ) та співавторів. Ця технологія вже знайшла своїх прихильників у багатьох країнах. Заключна доповідь цього засідання - «Вплив переривчастої нормобаричної гіпоксії та автономну нервову систему дітей - мешканців радіаційно забруднених територій» (Л.Лісуха, Київ) переконливо показала позитивну дію інструментальної оротерапії на зменшення радіоактивного забруднення організму та поліпшення якості нервової регуляції метаболічних функцій.

Ранкове засідання 14.05.2016 р. відкрилося лекцією професора А.Тихон (Молдова, Кишинів), присвяченою розгляду проблеми раціонального харчування, як невід'ємного компоненту здорового способу життя. Наступною виступала гостя з Великобританії Т.Вороніна, керівник Лондонської клініки антиейджингу, що протягом багатьох років успішно використовує розроблену в Україні технологію інструментальної оротерапії. Новий варіант аналізу варіабельності серцевого ритму у хворих із супутніми посттравматичними стресовими розладами розробили С.Мостовий та співавт. (Київ). Ця технологія $\epsilon$ особливо інформативною для діагностики осіб, постраждалих в АТО. Доповідь професора Ю.Кравченка (Київ) стосувалася аналогічного предмету за умов проведення тесту після тривалої адаптації до гіпоксії. Насамкінець виступив професор С.Харченко (Суми), який проаналізував прогноз смертності від виразкової хвороби залежно від вікового і територіального факторів в Україні. Засідання завершилося загальною дискусією, прийняттям резолюції та процедурою закриття симпозіуму.

У вестибюлі були розташовані експонати сателітної виставки нових приладів та апаратури. Відвідувачі мали можливість здійснити поглиблений автоматичний аналіз електрокардіограми та варіабельності сер- цевого ритму за новою розробленою в НАН України комп'ютерною програмою детального прогнозування стану міокарда (К.Апихтін, В.Петрухін, Ю.Горго, Москва-Київ). Усі бажаючі (а таких знайшлося дуже багато) мали можливість отримати інструментальну характеристику повноцінності діяльності стану своєї печінки за допомогою нового біофізичного приладу «Стеатометра». Завдяки автоматичному розрахунку коефіцієнта затухання відбитого тканинами печінки ультразвуку, нова технологія дає змогу діагностувати ранні ознаки виникнення ранніх ознак патології органа (О.Динник, Н.Кобиляк, А.Марусенко, Київ-Харків). Учасники зрілого та похилого віку відчули на собі омолоджуючий вплив штучного гірського повітря. Процедуру забезпечував апарат «Борей», виробництва медико-інженерного центру НОРТ НАН України, який за допомогою газоселективних мембран дає можливість людині дихати керованою атмосферою, що відтворює цілющі властивості гірського повітря курортів Швейцарії.

Велику увагу учасників симпозіуму та відвідувачів виставки було привернуто до сучасних розробок відділу клінічної патофізіології Інституту фізіології НАН України - інноваційної технології та пристрою для діагностики стану та якості кісткової тканини «Остеотест» і акустично модульованої магнітотерапії «АММТ-1 (М.Левашов, С.Сафонов, Київ). Крім того, були продемонстровані експериментальні моделі апаратів для акустичного вібромасажу органів дихання «ЕОЛ-М», загальної та локальної аероіоно- та магнітотерапії.

Принципово нові можливості візуального дослідження стану кровоносних судин дна ока людини надає створений Інститутом металофізики ім. Г.Курдюмова НАН України прилад, який користувався максимальною увагою відвідувачів. Відмінність і перспективність цієї апаратури і технології полягає у тому, що вона не потребує використання атропіну для дослідження та усуває можливість 
його негативних наслідків на організм. Якщо дослідження з атропіном триває не менше ніж 30 хв, то аналогічне дослідження за допомогою нового приладу завершується протягом 2-3 хв. Це створює можливість підвищувати продуктивність діагностики окулістів. Діяльність апарату демонстрував його винахідник академік І.Плюто. Київський центр «Фунготерапії, аюрведи та біорегуляції» представив цілу лінійку нових препаратів для фіто- i фунготерапії різних захворювань, також апаратуру для оцінки стану фізіологічних систем організму людини і біорезонансної терапії.

Культурна програма здійснювалася на території Зверинецької гори м. Києва у межах ді- ючого Іонінського монастиря. Під цією горою нещодавно, майже випадково, були відкриті стародавні печери дохристиянського періоду. Екзотична екскурсія у ці печери справила незабутні враження не тільки на іноземних гостей, але й на киян. Всі учасники симпозіуму висловили впевненість у надзвичайній продуктивності обговорення проблем біофізичної медицини та необхідності подальшого регулярного проведення таких зборів.

Видані до початку роботи симпозіуму тези доповідей учасників відкриті для загального доступу на сайті Інституту фізіології ім. О.О.Богомольця Національної академії наук України - www.biph.kiev.ua.

Оргкомітет 